\title{
Topical Effect of Pinneaple (Ananas comosus) Juice in Combustio Healing Process Measured by Granulation Process, Reepitelialisation and Angiogenesis
}

\author{
Cherry Azaria*, Achadiyani**, Reni Farenia*** \\ *Histology Department Faculty of Medicine Maranatha Christian University \\ Jalan Prof. drg. Suria Sumantri MPH No. 65 Bandung 40164 Indonesia \\ **Histology Department Faculty of Medicine Padjadjaran University \\ ***Physiology Department Faculty of Medicine Padjadjaran Universit \\ Jalan Pasteur 38 Bandung 40161 Indonesia \\ Email: cherry.azaria@gmail.com
}

\begin{abstract}
Skin protects the body from various trauma, such as high temperature trauma known as combustio. Pineapple (Ananas comosus) contains lots of substances such as bromelain, antioxidants, and zinc shown to accelerated healing process in previous experiments. Aim of this research was to analize the effect of topical pinneaple juice application in combustio healing process. The method was true experimental laboratory. Wistar rats' back skin were induced by $100^{\circ} \mathrm{C}$ iron plat untill $2^{\text {nd }}$ degree combustio occured, then divided into two groups $(n=20)$. The treatment group were given topical application of pinneaple juice, then the healing process were observed macroscopically and microscopically on day $0,3,7$, and 14. The result showed better wound healing in treatment group on day 14. MANOVA test showed topical application of pinneaple juice accelerated healing process $(p=0.001)$. Treatment group showed better histological structure changes, as seen from better granulation tissue formed ( $p=0.003)$ and reepithelization $(p=0,000)$, but not from angiogenesis $(p=0.733)$. Conclusion, topical application of pinneaple (Ananas comosus) juice accelerated healing process in $2^{\text {nd }}$ grade of combustio animal model measured by granulation maturation process and reepithelization process, but has no effect on angiogenesis.
\end{abstract}

Keywords : Ananas comosus juice, $2^{\text {nd }}$ degree combustio, granulation tissue, reepitelisation, angiogenesis. 


\title{
Efek Topikal Sari Buah Nanas (Ananas comosus) terhadap Proses Penyembuhan Luka Bakar berdasarkan Jaringan Granulasi, Reepitelisasi, dan Angiogenesis
}

\author{
Cherry Azaria*, Achadiyani**, Reni Farenia*** \\ *Bagian Histologi Fakultas Kedokteran Universitas Kristen Maranatha \\ Jalan Prof. Drg. Suria Sumantri MPH No.65 Bandung 40164 Indonesia \\ **Bagian Histologi Fakultas Kedokteran Universitas Padjadjaran \\ ****Bagian Fisiologi Fakultas Kedokteran Universitas Padjadjaran \\ Jalan Pasteur 38 Bandung 40161 Indonesia \\ Email: cherry.azaria@gmail.com
}

\begin{abstract}
Abstrak
Kulit berfungsi melindungi tubuh dari berbagai trauma, seperti trauma akibat luka bakar. Nanas (Ananas comosus) memiliki banyak zat seperti enzim bromelain, antioksidan, dan zinc yang pada berbagai penelitian menunjukkan kemampuan untuk mempercepat penyembuhan luka. Tujuan dari penelitian ini adalah untuk menganalisis efek sari buah nanas secara topikal pada proses penyembuhan luka bakar. Penelitian ini bersifat eksperimental laboratorik menggunakan hewan coba tikus Wistar yang diinduksi dengan pelat besi bersuhu $100^{\circ} \mathrm{C}$ sehingga terbentuk luka bakar tingkat II,yang dibagi menjadi 2 kelompok $(n=20)$. Kelompok perlakuan diberi $2 \mathrm{ml}$ sari buah nanas topikal $2 \mathrm{x} /$ hari, dan diamati proses penyembuhannya, baik secara makroskopis, dan mikroskopis berupa pembentukan jaringan granulasi, reepitelisasi, dan angiogenesis, pada hari ke 0, 3,7, dan 14. Hasil penelitian menunjukkan penyembuhan secara makroskopis yang lebih baik pada kelompok perlakuan pada hari ke-14. Analisis dengan uji statistik MANOVA menunjukkan adanya efek pemberian sari buah nanasterhadap proses penyembuhan $(\mathrm{p}=0.001)$. Perubahan secara mikroskopis terlihat dari jaringan granulasi $(\mathrm{p}=0.003)$ dan reepitelisasi $(\mathrm{p}=0.000)$ yang lebih baik pada kelompok perlakuan, namun tidak untuk angiogenesis $(\mathrm{p}=0.733)$. Penggunaan sari buah nanas(Ananas comosus) topikal mempercepat proses pembentukan jaringan granulasi dan proses reepitelisasi pada penyembuhan hewan model luka bakar tingkat II dalam hal pembentukan jaringan granulasi dan reepitelisasi, namun tidak berpengaruh terhadap angiogenesis.
\end{abstract}

Kata Kunci : sari buah Ananas comosus, luka bakar tingkat II, jaringan granulasi, reepitelisasi, angiogenesis 


\section{Research Article}

\section{Pendahuluan}

Kulit merupakan organ terbesar dalam tubuh manusia yang terutama berfungsi untuk melindungi tubuh dari berbagai jenis trauma baik secara mekanik ataupun kimiawi, seperti luka akibat suhu tinggi, atau yang dikenal dengan luka bakar. ${ }^{1,2}$

Luka bakar merupakan salah satu jenis luka akibat temperatur tinggi atau rendah yang dapat mengakibatkan kerusakan jaringan bahkan hilangnya jaringan, yang umum terjadi di masyarakat. Berbagai sumber trauma tersebut mencakup sumber listrik, bahan kimiawi, cahaya, radiasi, dan lain sebagainya. ${ }^{3}$ Secara epidemiologis, angka kejadian luka bakar di Amerika Serikat mencapai 500.000 orang setiap tahunnya, sekitar 30\%-nya diakibatkan oleh suhu tinggi seperti oleh air panas. ${ }^{4,5}$

Kerusakan jaringan akibat luka bakar, dapat menyebabkan terjadinya berbagai macam perubahan secara molekuler, salah satunya adalah munculnya berbagai radikal bebas yang akan berpengaruh dalam proses penyembuhan. Perbedaan tingkat kerusakan jaringan yang terjadi akan memungkinkan munculnya bekas luka (scar) bahkan kecacatan, yangdapat mengganggu baik fungsi maupun dari segi kosmetik, dan pada akhirnya dapat menurunkan kualitas hidup seseorang. ${ }^{3}$

Luka bakar dapat dibagi menjadi 3 tingkat berdasarkan gambaran histologis, yaitu tingkat I (superfisial), tingkat II A (superfisial parsial) dan tingkat II B (deep partial), dan tingkat III (deep). Luka bakar tingkat II, yaitu IIA maupun IIB lebih sering diakibatkan oleh air panas, bahan kimia, api, maupun aliran listrik. Pada luka bakar tingkat II, kerusakan jaringan ditandai dengan adanya kulit yang melepuh (blister) hingga lapisan epidermis, bahkan terkadang sebagian lapisan dermis menghilang, walaupun secara keseluruhan masih melekat dengan jaringan di bawahnya. ${ }^{3}$ Luka bakar tingkat II pada umumnya dapat menyebabkan bekas luka (scar) apabila tidak segera ditangani. Hal ini berbeda dengan luka bakar tingkat I yang relatif dapat sembuh dengan baik.

Waktu penyembuhan yang dibutuhkan pada apabila terjadi luka bakar tingkat II adalah sekitar 1-6 minggu. ${ }^{3}$ Proses penyembuhan akan terjadi melalui 3 tahap, yaitu fase inflamasi, fase proliferasi (reepitelisasi), dan fase remodeling; dengan melibatkan berbagai faktor yang berbeda untuk masing-masing tahap tersebut. Pada fase inflamasi, akan dikeluarkan banyak radikal bebas oksigen sitotoksik akibat adanya aktivasi neutrofil dan aktivasi komplemen, seperti hidrogen peroksida dan superoksida. ${ }^{7}$ Pada fase proliferasi mulai terbentuk banyak kapiler darah yang berfungsi untuk memberikan nutrisi yang cukup untuk berjalannya proses penyembuhan (angiogenesis), dan terjadi pembentukan matriks ekstraseluler sehingga akan merangsang berbagai enzim degradasi matriks yang dibutuhkan pada fase selanjutnya, juga migrasi sel-sel 


\section{Research Article}

epitel ke daerah luka. ${ }^{8}$ Pada fase remodeling terutama terjadi maturasi jaringan luka dan kapiler darah hingga terjadi penyembuhan yang sempurna. ${ }^{9}$

Proses penyembuhan ini dapat terhambat oleh berbagai penyebab, seperti terjadinya infeksi. Maka sangatlah penting untuk menjaga kebersihan luka dengan cara penanganan luka yang baik. Oleh sebab itu, penting untuk memikirkan apakah terapi yang digunakan untuk membantu kesembuhan luka, juga memiliki efek antiseptik untuk mencegah terjadinya infeksi sekunder. ${ }^{3,10}$

Proses penyembuhan luka bakar sangat penting sehingga banyak sekali jenis pengobatan yang digunakan untuk mempercepat penyembuhannya dan kebanyakan tidak murah. Sekarang ini dengan berbagai perkembangan di bidang herbal memungkinkan didapatkannya pengobatan alternatif. Contohnya penelitian mengenai berbagai jenis tanaman buah seperti pepaya yang mengandung enzim papain dan bahan alkaloid seperti carpain, atau bahan lain seperti madu yang mengandung berbagai vitamin, asam amino, dan hidrogen peroksida, dan lidah buaya yang mengandung berbagai jenis asam amino dan vitamin untuk mengobati luka bakar. Pada penelitian yang menggunakan pepaya, ternyata efek antiinflamasi diberikan oleh enzim papain, sedangkan efek antiseptik diberikan oleh carpain. Pada penggunaan lidah buaya, berbagai asam amino dan vitamin dapat bersifat sebagai antioksidan dan menyediakan energi untuk penyembuhan. Pada penggunaan madu vitamin bersifat sebagai antioksidan. ${ }^{6,11,12}$

Nanas (Ananas comosus) merupakan salah satu buah yang banyak terdapat di berbagai daerah tropis di dunia dengan berbagai variasi sesuai dengan keadaan geografis masing-masing daerah, termasuk Indonesia, dan dapat didapatkan dengan harga yang relatif murah. Nanas banyak disukai karena rasanya yang manis dan banyak mengandung air. Kandungan yang terdapat dalam nanas mencakup enzim bromelain yang merupakan suatu jenis enzim protease dengan berbagai kegunaan sebagai antiinflamasi, anti-invasif, dan anti metastase. ${ }^{6,11-15}$ Berbagai penelitian juga telah membuktikan bahwa enzim tersebut memiliki efek terhadap penyembuhan luka sayat. Kandungan lain pada nanas yaitu vitamin A, vitamin C, protein, karbohidrat, lemak, zat besi, fosfor, zinc, mangan, dan lain sebagainya. ${ }^{16}$ Vitamin A dan vitamin $\mathrm{C}$ sebagai antioksidan, juga zinc yang mengatur penyediaan energi dan nutrisi untuk sel akan dapat mendukung berjalannya fase penyembuhan luka. ${ }^{11}$ Selain dengan beragamnya kandungan dalam nanas, tingkat keasaman yang dimiliki oleh nanas muda pada khususnya akan memiliki sifat antiseptik sehingga mampu menghambat terjadinya infeksi sekunder. ${ }^{6,11-14}$

Tujuan penelitian ini adalah untuk menganalisis efek sari buah nanas secara topikal pada proses penyembuhan luka bakar. 


\section{Research Article}

\section{Metode}

Penelitian ini merupakan penelitian eksperimental laboratoris sungguhan dengan rancangan acak sederhana. Objek penelitian adalah Tikus jantan Wistar dewasa (8-10 minggu), berat 200-250 gram yang dibeli di Laboratorium hewani Ilmu hayati Institut Teknologi Bandung, berjumlah 40 ekor berdasarkan rumus besar sampel Mead. Hewan coba yang telah diadaptasi, dianestesi terlebih dahulu menggunakan eter 1-2 ml/kgBB, kemudian diinduksi luka bakar tingkat II dengan cara menempelkan plat yang direndam 5 menit dalam air panas $100^{\circ} \mathrm{C}$ dan ditempelkan selama 30 detik di kulit hewan coba yang telah dicukur, hingga timbul bulla.

Hewan coba kemudian dibagi menjadi 2 kelompok ( $n=20)$, yaitu kelompok kontrolyang akan diberikan wound toilet berupa olesan $\mathrm{NaCl}$ fisiologis, dan kelompok perlakuan yang akan diberikan wound toilet (olesan $\mathrm{NaCl}$ fisiologis) dan sari buah nanas masing-masing sebanyak 2 $\mathrm{ml}$ yang berasal dari 100 gr nanas, secara topikal menggunakan kasa steril pada jaringan kulit yang luka, sebanyak dua kali sehari.

Pada hari ke-0, ke-3, ke-7, dan ke-14, diamati perkembangan proses penyembuhan luka bakar pada 5 ekor hewan coba dari masing-masing kelompok penelitian dengan cara mengukur lebar dan panjang dari luka bakar, kemudian diamati ada tidaknya tanda-tanda infeksi sekunder berupa nanah. Setelah dilakukan pengukuran, masing-masing hewan coba dianestesi menggunakan eter 1-2 ml/kgBB, kemudian diambil jaringan kulitnya sesuai ukuran luka (2,5x2,5 cm pada awal penelitian, sampai lapisan dermis) dan dibuat preparat histologis potongan melintangsehingga seluruh bagian kulit dapat diamati, dan dengan pewarnaan rutin HE (Hematoksilin Eosin). ${ }^{3,9}$ Setelah itu luka bekas pengambilan preparat dijahit situasional dan ditutup menggunakan kasa steril.

Secara mikroskopis, akan diamati kondisi daerah kulit yang mengalami luka bakar, berupa hilangnya lapisan epidermis (tidak tampak adanya epitel), rusaknya lapisan dermis (jaringan ikat yang rusak dan tidak beraturan), dan adanya sebukan sel radang tanpa disertai adanya nekrosis atau nanah pada jaringan; yang akan dibandingkan dengan kondisi kulit sekitar luka yang masih sehat (tampak dengan utuhnya epitel, lapisan jaringan ikat dermis yang utuh, dan tidak ada sebukan sel radang).

Pengambilan data untuk variabel ketebalan jaringan granulasi diukur pada tempat yang menunjukkan adanya pembentukan jaringan ikat dan pembuluh darah baru di bagian bawah luka (daerah granulasi), pada 5 (lima) lapang pandang (perbesaran 40x), dan dilakukan sebanyak 5 kali pada tiap lapang pandangnya, dengan menggunakan program komputer, kemudian dirataratakan. 


\section{Research Article}

Pengambilan data untuk variabel angiogenesis diambil dengan cara menghitung jumlah kapiler, yang tampak berupa saluran dilapisi satu lapis endotel pada bagian bawah luka, pada 5 (lima) lapang pandang (perbesaran 40x) yang berbeda.

Pengambilan data untuk variabel reepitelisasi, berupa pembentukan epitel baru pada daerah luka yang tumbuh sampai mencapai ketinggian yang sama dengan kulit sehat, diukur mulai dari membrana basalis sampai permukaan kulit, diukur pada 5 (lima) lapang pandang (perbesaran 40x), dan dilakukan sebanyak 5 kali pengukuran pada tiap lapang pandangnya, dengan menggunakan progam komputer, kemudian dirata-ratakan.

Pengolahan data menggunakan uji statistik MANOVA (Multivariate Analysis of Variance) untuk melihat efek variabel bebas (pemberian olesan sari buah nanas) terhadap tiaptiap variabel terikat (ketebalan jaringan granulasi, reepitelisasi, dan angiogenesis).

\section{Hasil}

Secara umum penyembuhan luka bakar tingkat II secara makroskopis pada kelompok perlakuan lebih cepat terjadi bila dibandingkan dengan kelompok kontrol negatif. Pengamatan pada hari ke-3 dan ke-7, belum menunjukkan adanya perbedaan gambaran penyembuhan luka pada kedua kelompok. Hal tersebut terlihat dari jaringan kulit pada kedua kelompok masih tampak kemerahan. Namun pada hari ke-14, terlihat bahwa permukaan kulit hewan coba kelompok perlakuan secara umum sudah tampak seperti kulit normal, dan tidak tampak adanya pembentukan bekas luka (scar).

Pada pengukuran panjang dan lebar luka, tampak bahwa pada hari ke-3 dan ke-7, ukuran luka kedua kelompok penelitian sudah mulai mengecil. Akan tetapi, perbedaan nyata tampak pada hari ke-14, yang menunjukkan ukuran luka pada kelompok perlakuan lebih kecil dibandingkan kelompok kontrol (Tabel 1).

\section{Tabel 1 Perbandingan Ukuran Rata-Rata Luka Bakar secara Makroskopis (Sentimeter) pada Kelompok Kontrol dan Perlakuan Serial}

\begin{tabular}{llcc}
\hline & & Kontrol negatif & Perlakuan \\
\hline \multirow{2}{*}{ Hari 0 } & panjang & 2.6 & 2.56 \\
& lebar & 2.4 & 2.4 \\
\multirow{2}{*}{ Hari 3 } & panjang & 1.2 & 1.04 \\
& lebar & 1.16 & 1.04 \\
\multirow{2}{*}{ Hari 7 } & panjang & 0.88 & 0.9 \\
& lebar & 0.68 & 0.68 \\
\multirow{2}{*}{ Hari 14 } & panjang & 0.68 & 0.28 \\
& lebar & 0.48 & 0.14 \\
\hline
\end{tabular}




\section{Research Article}

Secara mikroskopis, proses penyembuhan sempurna dinilai berdasarkan keutuhan lapisan epidermis (epitel permukaan) dan lapisan dermis kulit. Gambar 1 menunjukkan perbandingan gambaran luka secara mikroskopis pada hari 0, 3, 7, dan 14 secara umum. Tampak pada hari ke-0, di beberapa tempat epitel hilang, tidak terlihat papilla corii, dan lapisan dermis rusak. Pada hari ke-3, tampak epitel mulai terbentuk walau masih belum utuh di seluruh permukaan dan adanya jaringan granulasi yang mulai terbentuk, terdiri atas sel-sel radang dan matriks ektraseluler, juga ditemukan kapiler-kapier darah. Pada hari ke-7, tampak epitel sudah melapisi seluruh permukaan kulit walau masih tampak tipis, jaringan granulasi sudah mulai matur dan mulai berubah menjadi dermis kulit. Pada hari ke-14, tampak lapisan epitel sudah sama seperti epitel pada kulit normal dan lapisan dermis sudah kembali utuh.
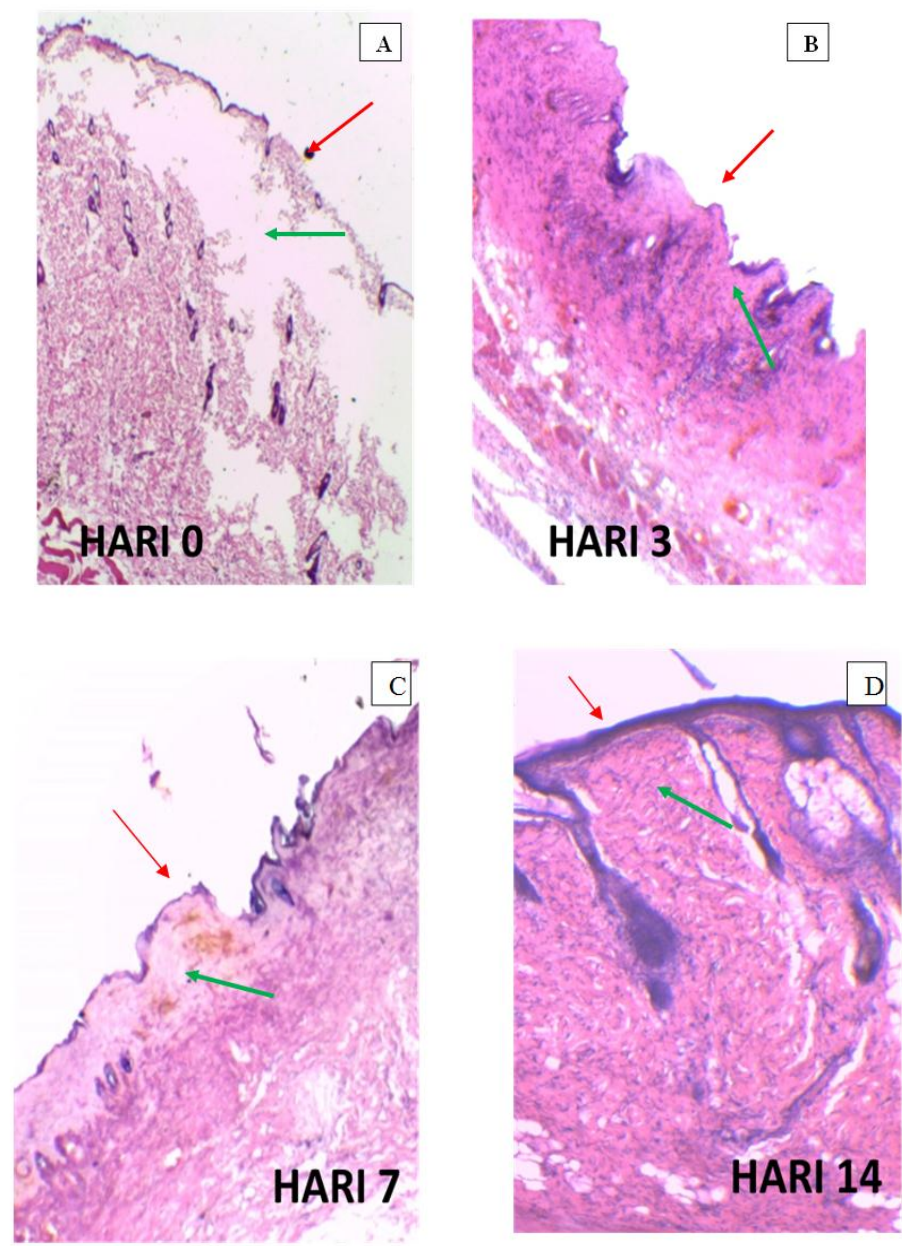

Gambar 1 Berbagai Perubahan Gambaran Mikroskopis Kulit dengan Pembesaran 40x Keterangan:

A. Hari ke-0, epitel (panah merah), lapisan dermis (panah hijau) rusak; B. Hari ke-3, epitel masih hilang dan ada jaringan granulasi (panah hijau) di lapisan dermis; C. Hari ke-7, epitel lengkap namun tipis dan jaringan granulasi (panah hijau) mulai matur; D. Hari ke-14, epitel (panah merah) lengkap dan normal, lapisan dermis (panah hijau) utuh 


\section{Research Article}

Hasil pengamatan serial secara mikroskopis terhadap jaringan granulasi yang terbentuk pada kelompok kontrol menunjukkan bahwa pada hari ke 3 jaringan granulasi belum terlalu banyak dan ditemukan banyak sel radang, sedangkan di hari ke-7 jaringan granulasi sudah meliputi seluruh jaringan. Sedangkan pada kelompok perlakuan tampak pada hari ke-3 jaringan granulasi sudah meliputi seluruh jaringan, dan pada hari ke-7 jaringan granulasi tersebut sudah matur dan mulai membentuk lapisan dermis. Pada lapang pandang yang sama juga dilakukan pengukuran ketebalan jaringan granulasi, yang menunjukkan hasil rata-rata yang berbeda antara kedua kelompok pada hari ke-7 (kelompok kontrol negatif 176.650 $\pm 84.804 \mu \mathrm{m}$ dan kelompok perlakuan $462.389 \pm 39.691 \mu \mathrm{m})$, seperti terlihat pada Tabel 2, dengan hasil uji statistik MANOVA yang signifikan ( $\mathrm{p}=0.003$ ). Hal tersebut menunjukkan adanya efek pemberian Ananas comosus terhadap ketebalan jaringan granulasi secara serial.

Tabel 2 Hasil Perubahan Ketebalan Jaringan Granulasi

\begin{tabular}{crrrr}
\hline & \multicolumn{3}{c}{$\begin{array}{c}\text { Ketebalan jaringan granulasi }(\mu \mathrm{m}) \\
\text { Mean } \pm \text { SD }\end{array}$} & \multirow{2}{*}{$\mathrm{p}^{*}$} \\
\cline { 3 - 4 } & & \multicolumn{1}{c}{ Kontrol negatif } & \multicolumn{1}{c}{ Perlakuan } & \\
\hline 0 & 5 & $0,000 \pm 0,000$ & $0,000 \pm 0,000$ & \\
3 & 5 & $104,372 \pm 93,640$ & $133,858 \pm 32,445$ & \multirow{2}{*}{0,003} \\
7 & 5 & $176,650 \pm 84,804$ & $462,389 \pm 39,691$ & \\
14 & 5 & $90,775 \pm 88,364$ & $78,098 \pm 26,583$ & \\
\hline Uji MANOVA & & & &
\end{tabular}

Penghitungan jumlah kapiler pada setiap lapang pandang terhadap kedua kelompok penelitian, menunjukkan adanya perbedaan rata-rata jumlah kapiler antara kelompok kontrol negatif dan kelompok perlakuan sejak hari ke-0 (kelompok kontrol negatif 5.00 \pm 0.000 kapiler/ LP dan kelompok perlakuan 10.00 \pm 2.000 kapiler/ LP). Pada hari ke-14, rata-rata jumlah kapiler pada kelompok kontrol negatif (12.67 \pm 3.215 kapiler/ LP) lebih banyak dibanding kelompok

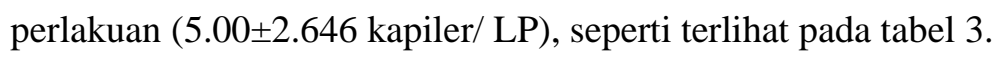




\section{Research Article}

Tabel 3 Angiogenesis (jumlah kapiler/ LP)

\begin{tabular}{|c|c|c|c|c|}
\hline \multirow[t]{2}{*}{ Hari ke- } & \multirow[t]{2}{*}{$\mathrm{N}$} & \multicolumn{2}{|c|}{$\begin{array}{c}\text { Jumlah kapiler/ LP } \\
\text { Mean } \pm \text { SD }\end{array}$} & \multirow[t]{2}{*}{$\mathrm{P}^{*}$} \\
\hline & & Kontrol negatif & Perlakuan & \\
\hline 0 & 5 & $5,00 \pm 0,000$ & $10,00 \pm 2,000$ & \multirow{4}{*}{0,733} \\
\hline 3 & 5 & $3,67 \pm 2,082$ & $6,33 \pm 3,055$ & \\
\hline 7 & 5 & $6,00 \pm 2,646$ & $4,67 \pm 1,528$ & \\
\hline 14 & 5 & $12,67 \pm 3,215$ & $5,00 \pm 2,646$ & \\
\hline
\end{tabular}

Uji statistik dari hasil pengukuran rata-rata jumlah kapiler kedua kelompok penelitian, ternyata tidak mendapatkan hasil yang signifikan $(\mathrm{p}=0,733)$. Hal ini menunjukkan tidak adanya pengaruh pemberian Ananas comosus topikal terhadap proses angiogenesis pada penyembuhan luka (Tabel 3). Dari hasil terlihat rata-rata jumlah kapiler mengalami peningkatan pada hari ke7, sedangkan jumlah kapiler paling banyak pada kelompok perlakuan terjadi pada hari ke-0 yang selanjutnya mengalami penurunan dan kembali meningkat pada hari ke-14.

Pengamatan proses reepitelisasi menunjukkan bahwa pada hari ke-0 tidak ditemukan adanya epitel permukaan pada semua hewan coba di kedua kelompok. Kemudian di kelompok perlakuan, seiring bertambahnya waktu terlihat epitel mulai terbentuk, mulai dari bagian dasar luka, dan mencapai ketebalan yang sama seperti kulit normal, atau telah terbentuk dengan sempurna pada hari ke-14. Pada kelompok perlakuan juga, tidak tampak adanya pembentukan jaringan ikat yang berlebihan (scar). Sedangkan pengamatan pada kelompok kontrol negatif, menunjukkan mulai terbentuknya epitel, namun belum terjadi pembentukan epitel secara sempurna pada semua hewan coba di kelompok ini,meskipun telah memasuki hari ke-14.

Tabel 4 Hasil Pengukuran Reepitelisasi pada Proses Penyembuhan Luka Bakar Tingkat II

\begin{tabular}{|c|c|c|c|c|}
\hline \multirow[t]{2}{*}{ Hari ke- } & \multirow[t]{2}{*}{$\mathrm{n}$} & \multicolumn{2}{|c|}{$\begin{array}{c}\text { Ketebalan epitel }(\mu \mathrm{m}) \\
\text { Mean } \pm \mathrm{SD}\end{array}$} & \multirow[t]{2}{*}{$\mathrm{p}^{*}$} \\
\hline & & Kontrol negatif & Perlakuan & \\
\hline 0 & 5 & $0,000 \pm 0,000$ & $0,000 \pm 0,000$ & 0,000 \\
\hline 3 & 5 & $8,320 \pm 0,076$ & $11,151 \pm 3,395$ & \\
\hline 7 & 5 & $11,533 \pm 2,315$ & $20,328 \pm 6,476$ & \\
\hline 14 & 5 & $20,880 \pm 8,012$ & $42,217 \pm 5,557$ & \\
\hline
\end{tabular}

*Uji MANOVA 


\section{Research Article}

Pengukuran ketebalan pertumbuhan epitel hari ke-3 menunjukkan tidak terlalu berbedanya rata-rata ketebalan epitel yang barupada kedua kelompok penelitian (kontrol negatif $8,320 \pm 0,076 \mu \mathrm{m}$, kelompok perlakuan $11,151 \pm 3,395 \mu \mathrm{m})$. Mulai pada hari ke-7, adanya perbedaan rata-rata ketebalan epitel baru ini mulai tampak, dan bahkan pada hari ke-14 rata-rata ketebalan epitel baru pada kelompok perlakuan hampir mencapai dua kali lipat ketebalan epitel pada kelompok kontrol negatif (kelompok kontrol negatif 20,880 $\pm 8,012 \mu \mathrm{m}$ dan kelompok perlakuan $42,217 \pm 5,557 \mu \mathrm{m})$.

Analisis uji statistik menunjukkan nilai yang signifikan $(\mathrm{p}=0,000)$. Hal tersebut membuktikan adanya pengaruh pemberian Ananas comosus terhadap kecepatan pertumbuhan epitel baru, yang ditunjukkan adanya reepitelisasi pada proses penyembuhan luka (Tabel 4).

\section{Diskusi}

Dari hasil penelitian secara makroskopis terlihat perbedaan ukuran luka dan keadaan kulit antara kedua kelompok hewan coba yang diteliti. Perbedaan tersebut terlihat jelas pada pengamatan hari ke-14. Pada kelompok perlakuan, tampak bahwa kulit hampir semua hewan coba sembuh sempurna dan tidak tampak adanya bekas luka. Hal ini menunjukkan pemberian sari buah Ananas comosus secara topikal berpengaruh terhadap proses penyembuhan luka dan tidak berlebihan dalam merangsang proses penyembuhan sehingga tidak menimbulkan bekas luka. ${ }^{3,10}$

Adanya perbedaan gambaran makroskopis pada penelitian ini sejalan dengan pengamatan secara mikroskopis, yang menunjukkanadanya perbedaan yang jelas antara kelompok kontrol negatif dan kelompok perlakuan,pada waktu jaringan granulasi menjadi matur. Pada kelompok perlakuan, jaringan granulasi di semua hewan coba telah matur pada hari ke-7, sedangkan pada kelompok negatif hanya jaringan granulasi dari 2 ekor hewan coba yang telah matur. Hasil pengamatan mikroskopisyang signifikan setelah diujikan dengan uji MANOVA (Tabel 2), menunjukkan bahwa pemberian Ananas comosus mampu untuk membantu proses maturasi jaringan granulasi sehingga lapisan dermis dapat lebih cepat kembali ke normal. ${ }^{9}$

Hal ini diduga akibat kandungan yang terdapat dalam nanas salah satunya enzim bromelain yang bersifat sebagai antiinflamasi, anti-invasif, dan anti metastase. ${ }^{6,11-15}$ Selain bromelain, adanya kandungan vitamin A, dan vitamin C yang berperan sebagai antioksidan, juga zinc yang mengatur penyediaan energi dan nutrisi untuk sel akan dapat mendukung berjalannya fase penyembuhan luka. ${ }^{11}$

Selain perbedaan pembentukan jaringan granulasi, proses reepitelisasi, yang merupakan proses proliferasi dengan pembentukan sel-sel epitel yang baru untuk menutup rongga pada 


\section{Research Article}

jaringan kulit akibat trauma, juga menunjukkan adanya perbedaan yang jelas antara kelompok kontrol negatif dan kelompok perlakuan, seperti terlihat pada tabel 4. Pada hari ke-0 terlihat tidak adanya lapisan epitel pada kedua kelompok penelitian, namun pada hari ke-14, seluruh hewan coba pada kelompok perlakuan telah mengalami reepitelisasi sempurna (mencapai ketinggian yang sama dengan kulit normal di sekitarnya) sedangkan pada kelompok kontrol negatif, reepitelisasi sempurna baru terjadi pada 3 hewan coba.

Gambaran tersebut sangat signifikan bila diuji dengan uji statistik MANOVA (Tabel 4). Hal tersebut menunjukkan bahwa penggunaan sari buah Ananas comosus secara topikal dapat mempercepat proses reepitelisasi tanpa menyebabkan bertumbuhnya jaringan ikat yang berlebihan sebagai indikator terbentuknya scar atau bahkan keloid. ${ }^{12,15}$

Proses penyembuhan luka merupakan suatu proses yang terdiri atas beberapa tahap yang saling tumpang tindih. Tahap pertama, yaitu tahap inflamasi, akan mulai berjalan dalam hitungan menit sejak awal terjadinya luka. Tahap ini akan berjalan hingga 2-3 hari setelah trauma, bahkan ada yang mencapai 2 minggu sehingga dapat memperlambat penyembuhan. Selanjutnya, akan terbentuk jaringan epitel untuk menutupi luka dengan jaringan granulasi di bawahnya, yang memungkinkan perbaikan jaringan ikat di bawah epitel dan pembentukan pembuluh darah baru yang terjadi dalam hitungan hari. Disebutkan bahwa pada hari ke-7 hingga hari ke-9 sesudah proses reepitelisasi, pembentukan membrana basalis epitel sudah sempurna, dan perbaikan luka mencapai puncaknya pada minggu kedua setelah trauma., ${ }^{3,89}$

Jaringan granulasi merupakan bagian yang cukup penting dalam penyembuhan luka, karena jaringan inilah yang akan menjadi stroma baru dari jaringan yang mengalami luka. Isi dari jaringan granulasi mencakup fibroblas, fibronektin, asam hyaluronat, dan kapiler-kapiler darah. ${ }^{8,9,17-19}$ Selanjutnya bekuan-bekuan darah ini akan digantikan oleh sel-sel epidermis yang membentuk lapisan paling luar dari jaringan. Proses ini akan terjadi pada hari ke-3 sampai ke-4 setelah terjadinya luka, dan dikenal dengan istilah fibroplasia, yang salah satunya mencakup proliferasi fibroblas sebagai dasar pembentukan jaringan granulasi. ${ }^{902-22}$ Proses migrasi dan proliferasi fibroblas dipengaruhi oleh berbagai faktor pertumbuhan, seperti PDGF dan TGF- $\beta$, $E P G$ dan $F G F$, serta rendahnya kadar oksigen pada luka. Tepat saat proses angiogenesis dimulai, kebutuhan jaringan akan oksigen terpenuhi, sehingga proses granulasi akan berakhir. ${ }^{22}$

Sayangnya, pada pengamatan secara mikroskopis terhadap angiogenesis pada penelitian ini menunjukkan hasil yang tidak signifikan, yang berarti pemberian Ananas comosus tidak berpengaruh terhadap proses angiogenesis. Namun apabila diamati dari seluruh hasil penelitian, tampaknya proses agiogenesis pada kelompok perlakuan lebih cepat terjadi dan lebih cepat mencapai jumlah yang cukup bila dibandingkan kelompok kontrol negatif, yang tampak sejalan 


\section{Research Article}

dengan alur terbentuk dan menjadi maturnya jaringan granulasi dan jaringan epitel pada kelompok perlakuan yang telah dibahas sebelumnya. Pada hasil juga tampak adanya perbedaan jumlah kapiler pada awal terjadinya luka. Hal ini merupakan salah satu keterbatasan penelitian ini yang hanya menggunakan pewarnaan rutin HE, sehingga mengandalkan kemampuan untuk mengamati saluran-saluran yang dilapisi endotel sebagai kapiler. Apabila kapiler tersebut kolaps, maka akan sulit diamati.

Proses agiogenesis dibutuhkan untuk mempertahankan jaringan granulasi yang baru terbentuk, dengan cara menghantarkan berbagai nutrisi yang menunjang proses tersebut.Pada keadaan normal, awal terbentuknya jaringan granulasi terjadi pada hari ke-3 setelah trauma, yang pada pengamatan mikroskopis akan banyak ditemukan kapiler darah sehingga jaringan granulasi tampak berwarna merah gelap. Selanjutnya pada akhir fase granulasi yang dicapai antara hari 7-14, akan terjadi regresi kapiler darah, sehingga warna jaringan granulasi akan lebih pucat. Apabila jaringan granulasi yang telah terbentuk mendapatkan vaskularisasi yang baik, maka stroma jaringan akan lebih cepat terbentuk sempurna. Pada awal terjadinya luka, invasi kapiler terjadi dengan karakteristik perdarahan di antara banyak kapiler dan awal terbentuknya bekuan fibrin. $^{8,9,20-22}$

Salah satu cara mempercepat munculnya angiogenesis antara lain dengan menghilangkan berbagai faktor penghambat dari terbentuknya angiogenesis. Hal ini dapat dilakukan dengan cara mengurangi jumlah radikal bebas yang muncul di dalam jaringan setelah terjadinya trauma. Faktor yang dapat mengurangi jumlah radikal bebas di antaranya adalah berbagai jenis antioksidan, seperti vitamin $\mathrm{C}$ yang terkandung dalam sari buah Ananas comosus. $^{6,11,12,16,22}$

\section{Simpulan}

Pemberian sari buah nanas (Ananas comosus) secara topikal mempunyai efek mempercepat maturasi jaringan granulasi, dan reepitelisasi, tetapi tidak mempercepat terjadinya proses angiogenesis pada penyembuhan hewan model luka bakar tingkat II.

\section{Daftar Pustaka}

1. Moore K.L. Dalley AF. Clinically oriented anatomy $5^{\text {th }}$ ed. Philadelphia: Lippincott Williams \& Wilkins; 2006. p. 232.

2. Gray H. Anatomy: The anatomical basis of clinical practice. $40^{\text {th }}$ ed. Churchill Livingstone; 2008. P. 1135-47.

3. Evers LH, Bhavsar D, Maila P. The biology of burn injury. 2010;777-83.

4. World Health Organization [www.who.int], Disease and injury country estimates. [Cited 2009]. WHO; Available from: http://www.who.int/healthinfo/global burden disease/estimates country/en/?

5. Walls R., Ratey J.J. SRI. Rosen's emergency medicine: concept \& clinical practice. St. Louis: Mosby; 2009. p. $1-4$ 


\section{Research Article}

6. Shuid AN, Anwar MS, Yusof AA. The effects of carica papaya Linn . Latex on the Healing of Burn Wounds in Rats. Jurnal Sains Kesihatan Malaysia. 2005;3(2):39-47.

7. Singh V, Devgan L, Bhat S, Milner SM. The pathogenesis of burn wound conversion. Annals of plastic surgery. 2007;59(1):109-15.

8. Sirica A. Cellular and mollecular pathogenesis. Lippincott-Raven; 1996. p.37-108

9. $\quad$ Singer A., Clark RA. Cutaneous wound healing. N Engl J Med. 1999;341(10):738-46

10. Schultz G. The physiology of wound bed preparation in surgical wound healing and management; 2007. p.16.

11. Kartini M. Efek penggunaan madu dalam manajemen luka bakar. Jurnal Kesehatan. 2009;2(2):17-20

12. Hosseinimehr SJ, Khorasani G, Azadbakht M, Zamani P, Ghasemi M, Ahmadi A. Effect of aloe cream versus silver sulfadiazine for healing burn wounds in rats. Acta Dermatovenerologica Croatica. 2010;18(1):2-7.

13. U.K S, Singh A, Sharma S, Kumar M, Rai D, Agrahari P. Wound healing activity of kigelia pinnata bark extract. Asian Journal of Pharmaceutical and Clinical Research. 2010;3(4):12-4.

14. Nithya V, Brinda P, Anand KV. Wound healing activity of leonotis nepetaefolia br in wistar albino rats. Control. 2011;4(2):4-7.

15. Maurer HR. Bromelain: biochemistry , pharmacology and medical use. Mol. Life Sci. 2001;58:1234-45.

16. USDA. USDA Nutrient [database on the Internet]. Available from: http://www.whfoods.com/genpage.php?tname=foodspice\&dbid=34

17. MacKay D, Miller AL. Nutritional support for wound healing. Alternative medicine review: Journ of Clin Ther. 2003;8(4):359-77.

18. Keck M, Herndon DH, Kamolz LP, Frey M, Jeschke MG. Pathophysiology of burns. Wiener medizinische Wochenschrift.2009;159(13-14):327-36.

19. Prins A, Sa RD. Nutritional management of the burn patient. S Afr J Clin Nutr. 2009;22(1):9-15.

20. Cho E, Seddon JM, Rosner B, Willett WC, Hankinson SE. Prospective study of intake of fruits, vegetables, vitamins, and carotenoids and risk of age-related maculopathy. Arch Ophthalmol. 2004;122(6):883-92.

21. Wu SY, Hu W, Zhang B, Liu S, Wang JM, Wang AM. Bromelain ameliorates the wound microenvironment and improves the healing of firearm wounds. Journal of Surgical Research. 2012;176(2):503-9.

22. Tanaka H, Molnar JA. Vitamin $\mathrm{c}$ and wound healing. 2006;121-48. Available from: http://www.crenetbase.com/doi/abs/10.1201/9780203500231.ch8 